\title{
THE RECIPROCAL EFFECT BETWEEN SOIL WATER CONTENT AND THE SOIL BULK DENSITY ON THE GROWTH AND YIELD OF ONION (Allium cepa L.)
}

\author{
Pou Anda \\ Department of Geophysics, Halu Oleo University, Kendari, Indonesia \\ *Corresponding author \\ E-mail:pou_anda@ymail.com
}

\begin{abstract}
The SWC and the SBD play an important role in determining soil's suitability for agricultural uses because they affect various physical, chemical, and biology of soil properties. This field experiment aimed to investigate the reciprocal effect of the SWC and the SBD on the growth and yield of onion (Allium cepa L.). The experiment was layout in a randomized complete block design (RCBD) with three replications. This experiment consisted of one factor, namely, water (A) with four levels, namely, $(A 0=0$ liter, $A 1=4$ liters, $A 2=8$ liters, and $A 3=16$ liters $)$, and one variety endemic of local Tomia (V). The treatment consisted of $A 0 \mathrm{~V}, A 1 \mathrm{~V}, A 2 \mathrm{~V}$, and $A 3 V$. Parameters observed including plant height, leaf width, fresh bulb and dry bulb weight. The results showed that the different water levels treatment had a highly significant $(p<0.01)$ affected the $S W C$ and $S B D$. Also, simultaneously the $S W C$ and the $S B D$ had a high significance $(p<0.01)$ reciprocally influenced the plant height, leaf width, fresh and dry weight of onion. When the SWC increase, the growth and the yield of onion increase, and when (SBD) decreases, the growing and the yield parameters increases. The best result occurred at the pair of SWC and SBD values of $(28.52 \%, 1.2 \mathrm{~g} . \mathrm{m} 3)$ with $33.07 \mathrm{~cm}$ plant height, $1.3 \mathrm{~cm}$ leaf width, $51.67 \mathrm{~g}$ fresh weight, and 44.33 $g$ dry weight, followed by other pair of values of SWC and SBD. Through graphs, the analysis showed that SWC has a positive effect and SBD has a negative influence on the growth and yield of onion except at an appropriate value.
\end{abstract}

Keywords: onion parameters; reciprocal; quadratic equations; soil properties

\section{Introduction}

Knowing the soil physical properties such as soil water content (SWC) and soil bulk density (SBD), we can know the various physical properties of soil like compaction, soil strength and impedance properties, porosity, bearing capacity, field capacity conditions, etc. (Gautam et al., 2018). Besides, the determining of soil water content and soil bulk density play an important role because they are directly related to changes in the chemical and biological properties of the soil (Phogat et al., 2015); (Campbell, 1994) and therefore they have a direct influence on plant performance (Chakraborty \& Mistri, 2017). Even in the soil itself, soil bulk is more often to regarded to indicate an indicator of soil health (Shah et al., 2017; Bonfante et al., 2019).

The relationship between soil water content and soil bulk density is reciprocal (Hillel, 2004). It is in line with the finding of Ghosh, (2013) through a laboratory experiment that if the soil is wetted further, the extra water replaces some of the solid soil particles, and the dry density reduces as there is less material present. The same result also reported by Abidin et al. (2013) who predict the soil water content and soil bulk density using laboratory resistivity experiment. 
However, the effect of the two quantities on plants is also reciprocal (Hillel, 2004); (Nunes et al., 2016); (Korenkova and Urik, 2017). The essential of the statement could be concluded that each increase in soil bulk density was followed by decreasing in soil water content as indicated by decreasing the total porosity and micro-porosity and macro-porosity or increasing in resistance to penetration and wise versa. Thus, as a logical consequence, the soil water content will decrease.

Soil water content at the limits of field capacity conditions has a positive effect on onion plants (Anshar et al., 2011); (Fitsum et al., 2016), while soil bulk density above a certain value has a negative effect on onion plants (Pedersen et al., 2015); Elfadil \& Salih (2017). Anshar et al. (2011) reported that the bigger leaf area, fresh bulb weight per clump, and plant growth rate were observed at level $100 \%$ field capacity of soil water content. In line with this, Fitsum et al. (2016) argued that increasing of water level application could be mainly due to better availability of soil water content and sufficient absorbs nutrients which have enhancing effects on the vegetable growth of plants by increasing cell division and elongation especially in plants heightening process. Otherwise, Pedersen et al. (2015) found that improved crop growth could be achieved if soil bulk density increased due to compaction was avoided. Furthermore, there were also clear that higher soil bulk caused a lower yield of onion and lower macro-porosity compared to low soil (Nawas et al., 2013). Elfadil and Salih (2017) added that soil bulk density level of 1.4 g.m ${ }^{-3}$ up to $1.8 \mathrm{~g} . \mathrm{m}^{-3}$ the average plant height is decreased because the plant did not absorb enough moisture and nutrients from the soil. The objective of the research was (1) to assess the effect of soil water content and soil bulk density on the growths and yields of onion (Allium cepa L.) through an experiment with applying different water level treatments, and (2) to determine the reciprocal relationship between soil water content effect and soil bulk density effect on the growth and yield of onion.

\section{Materials and Methods}

\subsection{Experimental Setup}

The layout of the experiment was a randomized complete block design with three replications. The experiment consisted of one factor, namely, water (A) with four levels, i.e., ( $\mathrm{A} 0=0$ liter, $\mathrm{A} 1=4$ liters, $\mathrm{A} 2=8$ liters, and $\mathrm{A} 3=16$ liters), and one variety of local onion (V). Hence, the combination between $\mathrm{A}$ and $\mathrm{V}(\mathrm{AV})$ is called treatment consisted of $\mathrm{A} 0 \mathrm{~V}, \mathrm{~A} 1 \mathrm{~V}, \mathrm{~A} 2 \mathrm{~V}$, and A3V. Overall, there were twelve experiment soil plots in the study. The distance between blocks was $0.5 \mathrm{~m}$, and the distance between plots was $30 \mathrm{~cm}$. Each plot consisted of $1.5 \mathrm{~m}$ long and 1.0 $\mathrm{m}$ width, and it raised was about $20 \mathrm{~cm}$ from the soil surface to easier control (FAO, 2020). The arrangement of plant from row to rows and from plant to plants was $15 \mathrm{~cm}$ and $15 \mathrm{~cm}$. So, there are 48 plants per plot. Fifteen plants among these took randomly for analysis. 


\subsection{Location and time of Research Activity}

It was established an experiment at land in the northern part of the Usuku Sub-district Capital of Tomia, Wakatobi Regency, Indonesia (12356.383' E; 0545.606' S), 108 m above sea level. This location is suitable for onion cultivation because it is open, bright, maximum solar radiation, and the wind is free to blow (Hanelt, 1990);(Ali, 2017);(Khokhar, 2017). Moderate temperatures $\left(24-30^{\circ} \mathrm{C}\right)$ and good light intensity are essential to initiate abulbresponse (Nault et al., 2011). However, it has heavy soil, many gravels, and pasture. The entire research activity was for three months from October to December 2017, where dry season periods were still ongoing. Because of the local small farmer only plant in the rainy season, so that production never well-develops properly. Table 1 contained the climate elements in the region during the experiment run.

Table 1 Climate elements in the region

\begin{tabular}{ccccccc}
\hline Year & Months & $\begin{array}{c}\text { Mean temp. } \\
\left({ }^{\circ} \mathrm{C}\right)\end{array}$ & Humidity & $\begin{array}{c}\text { Win speed } \\
(\text { knot })\end{array}$ & Rain days & $\begin{array}{c}\text { Amount of rain fall } \\
(\mathrm{mm})\end{array}$ \\
\hline \multirow{2}{*}{2017} & October & 28.9 & 72 & 3 & 11 & 53.7 \\
& November & 28.2 & 78 & 2.6 & 4 & 185 \\
& December & 28.7 & 79 & 2.6 & 9 & 46.1 \\
\hline
\end{tabular}

Source: Betoambari Weather station, Bau-bau, Indonesia

\subsection{Materials Used}

The variety used to plant bought from the local market of Tomia. The supporting materials such as tarpaulin and water storage were also required to support the study. Tools used to plow and loosen the soil like a hoe, a shovel, a hammer, and additional tools such as a knife for cutting the neck of seeds, plastic containers, and plastic pockets used for storage. As a fertilizer, were used the NPK nutrients and kitchen ash.

Table 2. Physical, chemical, and biological properties of experimental soil $(0-20 \mathrm{~cm})$ before treatment

\begin{tabular}{lcl}
\hline \multicolumn{1}{c}{ Soil properties } & Values & \multicolumn{1}{c}{ Methods } \\
\hline Sand (\%) & 19.83 & Pipette Method [1] \\
Silt (\%) & 8.60 & \\
Clay (\%) & 71.57 & \\
pH & 6.58 & pH meter Model 130 \\
N total (\%) & 0.28 & Kjeldahl \\
P (ppm) & 37 & Bray \\
K (me.100g $\left.{ }^{-1}\right)$ & 0.31 & Bray \\
Organic material (\%) & 1.89 & Spectrophotometer \\
Organic carbon (\%) & 27.51 & Black \\
\hline
\end{tabular}

\subsection{Soil Sampling and Physicochemical Analysis}

It was collected twelve soil samples from different plots at the soil depth of 0-20 centimeters, where roots of onions concentrated (Zheng et al., 2013) in a zigzag pattern across the required area. Soil composite samples took using a soil auger, put in plastic pockets and brought to the laboratory immediately for analysis. Samples were taken three times, at the beginning growth stage, medium, and at bulb formation, and take as a mean value. The physicochemical and 
biological properties of soil were selected and then analyzed at the laboratory and their results showed in Table 2.

According to criteria by Hardjowigeno (1992) that $\mathrm{N}$ tot, $\mathrm{P}$, and $\mathrm{K}$ were in the medium category while organic matter $(\mathrm{OM})$ was very low, and organic carbon $(\mathrm{CO})$ was high. For soil $\mathrm{pH}$ 6.58, (Nikus and Mulugeta, 2010)stated that it was optimum for onion production. When natural nutrients were not enough, need to add the required criteria of NPK application to maximized onion production.

\subsection{Land Preparation}

The land preparation is well before planting and must be free from grasses and weeds. With a hoe and a hammer, soil plowed and loosened, separated gravel and soil fraction, and make it become three blocks with a distance of $50 \mathrm{~cm}$. Raised beds about $20 \mathrm{~cm}$ in height from the ground and marked twelve plots with $1 \mathrm{~m}$ long and 1.5 widths. The distance between plots one and another one was $40 \mathrm{~cm}$ in one block, respectively.

\subsection{Farming Practices}

Before planting, the field was free from grasses and weeds. One day before planting, the experiment site was sprinkled with kitchen ash and watering uniformly. The seeds were sorting and selecting to obtain the proper one. To make it easier for the seedlings to grow faster, cut off a third of the seedlings and plant them in the morning or late evening. If something did not grow or appear, it was immediately replaced by seedlings in a nursery specially prepared for it. In terms of there were plants that do not appear immediately replaced them with other plants from the nursery specially prepared for that purpose. Watering stops if it was raining until another next drought. Due to the drought period, to keep the water in the container always remains available, one supplied from the wells using a pickup truck. Because of the dry season, to avoid crop water deficiency, watering applied was scheduled for consecutive days in the morning or late afternoon during early growth, growth stages, and bulbs formation. The application of packaged NPK fertilizer at a dose of 15:15:15 twice during the experiment run on, at the vegetative growth stages, and the tuber filling stage. Watering stops when two weeks before harvest because the onion bulbs appear to be ripe. The harvest period occurs when approximately $75 \%$ of the plant tips are bent.

\subsection{Observed Parameters}

The onion parameters observed in this study are plant height, leaf width, fresh weight, and dry weight. Plant height was estimated from the soil surface to the top of the leaf in centimeters, the width of the leaf is measured at the part with the longer diameter length by tearing it in centimeters, and the fresh and dry bulb weight was balanced in grams. 


\subsection{Soil Water Content and Soil Bulk Measurement}

Soil samples composed of 20 were collected to analyze the soil available and soil value at 0 $-20 \mathrm{~cm}$ depth from 12 plots. The SWC on a mass basis in plots was analyzed by following the standard procedure of the gravimetric method, as (1):

$$
\Theta_{\mathrm{g}}=\left(\frac{\text { weight of moist soil-weight of oven dry soil }}{\text { weight of oven dry soil }}\right) \times 100 \%
$$

Soil bulk density values are required to convert gravimetric soil water content to volumetric soil water content. To calculate the soil bulk density is used relation (2).

$$
\rho_{\mathrm{b}}=\frac{\text { oven dry weight of soil }}{\text { volume of soil }}=\frac{\mathrm{M}_{\mathrm{s}}}{\mathrm{V}_{\mathrm{t}}}
$$

Soil water content in base volume using equation 3.

$$
\theta_{\mathrm{V}}=\theta_{\mathrm{g}} \times \rho_{\mathrm{b}}
$$

\subsection{Data Analysis}

To test the significance of the positive effect of water treatment on the onion parameters observed was performed using standard one-way analysis of variance in an Excel worksheet environment. Water treatment effect on soil water content and soil bulk density and the reciprocal effect of soil water content and soil bulk density on growth and yield parameters of onion was analyzed using one-way ANOVA and were considered significant when $p<0.05$ or $p<0.01$. When the treatment was significant, the least significant difference (LSD) by Dunken's multiple range comparisons was used for mean separation at $p=0.05$. Another analysis used to find out the reciprocal effect more clearly was used graph analysis through the mat-lab plotting program.

\section{Results and Discussion}

\subsection{Effect of Water Treatment on SWC and SBD}

The different water levels treatment was had highly significant $(\mathrm{p}<0.01)$ affected SWC and SBD. Increasing water levels treatment cased the SWC increase, and at the same time, the SBD was slightly decreased (Table 3). The role of water treatment, in this case, was to low soil bulk density (Hillel, 2004) in an appropriate value where seeds and soil are still in contact (Elfadil \& Salih, 2017). This phenomenon by Nunes et al. (2016) at the factorial scheme experiment with a combination between SBD and soil water tensions found that the behavior of soil water contents as a function of the water tension and influenced by SBD. On the other side, the correspondent water contents with using the soil water retention curve, according to SBD. The SBD is an indicator of soil health (Indoria et al., 2016) since it is related to various soil properties that affected crop performance (Haghi et al., 2015). In terms of low hydraulic conductivity, crust formation with high mechanical strength and low permeability by forcing and pressure on the aggregates. 
Table 3. Effect of water level treatment on SWC and SBD

\begin{tabular}{ccc}
\hline Treatments & SWC $(\%)$ & SBD $\left(\mathrm{g} / \mathrm{cm}^{3}\right)$ \\
\hline A0V & $22.84^{\mathrm{a}}$ & $1.35^{\mathrm{a}}$ \\
A1V & $24.90^{\mathrm{b}}$ & $1.29^{\mathrm{b}}$ \\
A2V & $27.15^{\mathrm{b}}$ & $1.24^{\mathrm{b}}$ \\
A3V & $28.52^{\mathrm{b}}$ & $1.20^{\mathrm{b}}$ \\
CV $(\%)$ & 6.32 & 5.94 \\
\hline
\end{tabular}

Same letters in each column different at 0.05 levels according to LSD test

\subsection{Reciprocal Effect of SWC and SBD on Growth and Yield of Onion}

As seen in Table 3, the SWC and SBD had a highly significant $(\mathrm{p}<0.01)$ effect on the plant height, leaf width, fresh and dry weight. The reciprocal effects between SWC and SBD on the components of growth and yield of onion, as shown in Table 4, describes clearly that SWC and SBD affect reciprocally. These results agreed with the state of Hillel (2004), (Phogat et al., 2015), and (Korenkova and Urik, 2017).

\subsection{The Growth Components}

The growth components involved in this study were plant height and leaf width (Table 4). The highest of plant height $(33.07 \mathrm{~cm})$ and highest of leaf width $(1.30 \mathrm{~cm})$ occurred at a maximum value of SWC (28.52\%), and a minimum value of SBD $\left(1.2 \mathrm{~g} . \mathrm{cm}^{-3}\right)$ followed by $27.15 \%$ and 1.24 g.cm ${ }^{-3}$ of SBD with a plant height $(30.70 \mathrm{~cm})$, and leaf width $(1.2 \mathrm{~cm}), 24.90 \%$, and $1.29 \mathrm{~g} . \mathrm{cm}^{-3}$

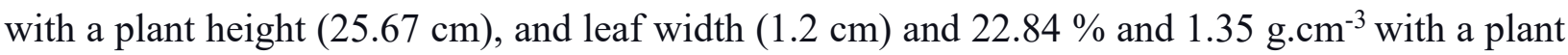
height $(22.67 \mathrm{~cm})$ and leaf width $(1.09 \mathrm{~cm})$ respectively. The positive effect of $\mathrm{SWC}$ enhancing on the growth and yield of onion increasing is in line with obtaining by Fitsum et al. (2016) and Tolossa (2021), while the negative effect of SBD increasing agreed with the finding by Elfadil and Salih (2017), and (Shah et al., 2012).

\subsection{The Yield Components}

The yield components included in the study were the fresh and the dry bulb weight. The weightiest of the onion fresh bulbs onion $(51.67 \mathrm{~g})$ and dry bulb weight $(44.33 \mathrm{~g})$ occurred at a maximum value of SWC (28.52\%) and a minimum value of SBD (1.2 g.cm $\left.{ }^{-3}\right)$, followed (27.15

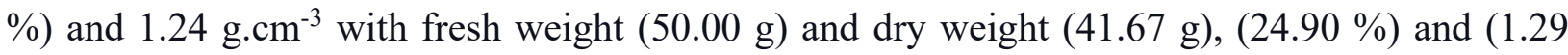
gcm3) with fresh bulbs onion $(46.67 \mathrm{~g})$ and dry weight $(36.67 \mathrm{~g})$, and $(22.84 \%)$ and $1.35{\mathrm{~g} . \mathrm{cm}^{-3}}^{-3}$ with fresh bulbs onion (41.30 g) and dry weight (28.33 g) respectively (Table 4).

Table 4. Reciprocal effect between SWC and SBD on growth and yield parameters of onion

\begin{tabular}{ccccccc}
\hline $\begin{array}{c}\text { SWC } \\
(\%)\end{array}$ & $\begin{array}{c}\text { SWC }_{\mathrm{V}} \\
(\%)\end{array}$ & $\begin{array}{c}\text { SBD } \\
\left(\mathrm{g} / \mathrm{cm}^{3}\right)\end{array}$ & $\begin{array}{c}\text { Plant height } \\
(\mathrm{cm})\end{array}$ & $\begin{array}{c}\text { Leaf width } \\
(\mathrm{cm})\end{array}$ & $\begin{array}{c}\text { Fresh bulb } \\
\text { weight }(\mathrm{g})\end{array}$ & $\begin{array}{c}\text { Dry bulb } \\
\text { weight }(\mathrm{g})\end{array}$ \\
\hline 22.84 & 30.83 & 1.35 & $22.67^{\mathrm{a}}$ & $1.09^{\mathrm{a}}$ & $41.30^{\mathrm{a}}$ & $28.33^{\mathrm{a}}$ \\
24.90 & 32.12 & 1.29 & $25.67^{\mathrm{b}}$ & $1.20^{\mathrm{b}}$ & $46.67^{\mathrm{b}}$ & $36.67^{\mathrm{b}}$ \\
27.15 & 33.67 & 1.24 & $30.70^{\mathrm{c}}$ & $1.20^{\mathrm{b}}$ & $50.00^{\mathrm{c}}$ & $41.67^{\mathrm{c}}$ \\
28.52 & 34.22 & 1.20 & $33.07^{\mathrm{d}}$ & $1.30^{\mathrm{c}}$ & $51.67^{\mathrm{C}}$ & $44.33^{\mathrm{d}}$ \\
CV $(\%)$ & - & - & 6.58 & 0.011 & 2.85 & 3.46 \\
LSD (0.05) & - & - & 2.18 & 0.09 & 1.97 & 1.94 \\
\hline
\end{tabular}

Same letters in each column of onion parameters are notsignificantly different at 0.05 levels according to LSD test 


\subsection{The Reciprocal Relationship}

Based on Table 4, further analysis providing the reciprocal relationship more clearly using the graph plotting under Mat-lab programming by way of accompanied both curves viz. SWC effect and SBD effect on the growth and yield of onion. Overall, Figure 1 describes that when soil water gradually increased, the onion parameters observed increase. Likewise, when SBD increase, the onion parameters decrease. A quadratics relationship between SWC and SBD and the growth and yield of onion agreed with the expected by Yahuza (2011), (Hanafiah, 2014), and (Wibisono, 2013). The onion growth and yield components increased with soil water content as days after transplanting following a growth curve from small height until reaching of the end of establishment stage; growing then quickly until reaching its maximum value, after that, if SWC become excessive and the yield declines (Wichelns, 2014). Similar with this characteristic have been given by (Zhang et al., 1999) that crop water productivity will decline throughout all values of applied water. So, this is quadratic in shape. The best onion growth and yield occurred in pairs of values

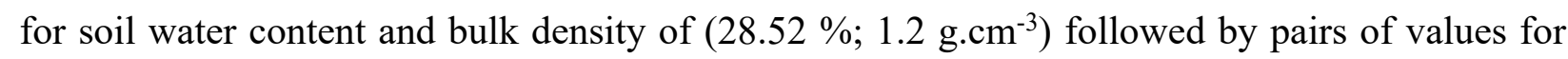

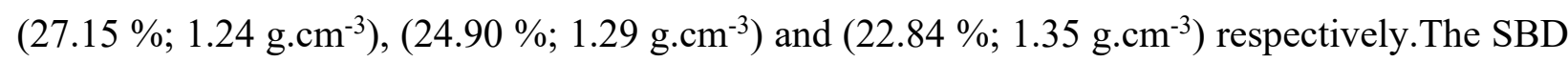
of $1.35 \mathrm{~g} . \mathrm{cm}^{-3}$ is high risk (Brus and van den Akker, 2018). The positive effect of SWC on growth and yield components as described through quadratic equations with an average of correlation coefficient 0.92 and determination coefficient of 0.86 (Table 5) like to Manullang et al. (2020) and Al-Jamal et al. (2000) description where y is the growth and yield components of onion (cm, g), $\mathrm{x}$ is the SWC $(\%)$.

Table 5 Effect of SWCand SBD on the growth and yield components

\begin{tabular}{llcc}
\hline \multicolumn{4}{c}{ Effect of SWC on the growth and yield of onion } \\
\hline Onion parameters & \multicolumn{1}{c}{ Equations } & $\mathrm{R}$ & $\mathrm{R}^{2}$ \\
\hline Plant height & $\mathrm{y}=-0.068 \mathrm{x}^{2}+4 \mathrm{x}-29$ & 0.89 & 0.79 \\
Leaf width & $\mathrm{y}=-0.008 \mathrm{x}^{2}+46 \mathrm{x}-5.3$ & 0.98 & 0.97 \\
Fresh weight & $\mathrm{y}=-0.21 \mathrm{x}^{2}+12 \mathrm{x}-1.3 \mathrm{e}+02$ & 0.90 & 0.81 \\
Dry weight & $\mathrm{y}=-0.17 \mathrm{x}^{2}+10 \mathrm{x}-1.1 \mathrm{e}+02$ & 0.91 & 0.83 \\
\hline \multicolumn{5}{c}{ Effect of SBD on growth and yield of onion } \\
\hline Plant height & $\mathrm{y}=-87 \mathrm{x}^{2}+2 \mathrm{e}+02 \mathrm{x}-88$ & 0.86 & 0.74 \\
Leaf width & $\mathrm{y}=-11 \mathrm{x}^{2}+25 \mathrm{x}-14$ & 0.98 & 0.97 \\
Fresh weight & $\mathrm{y}=-2.5 \mathrm{e}+02 \mathrm{x}^{2}+5.8 \mathrm{x}-2.9 \mathrm{e}+02$ & 0.86 & 0.74 \\
Dry weight & $\mathrm{y}=-2.2 \mathrm{e}+02 \mathrm{x}^{2}+0.2 \mathrm{x}-2.6 \mathrm{e}+02$ & 0.98 & 0.98 \\
\hline
\end{tabular}

Inversely, the negative effect of SBD on growth and yield components as explained by the quadratic equations with an average of correlation 0.97 and determination coefficient of 0.94 (Table 5) also as to Manullang et al. (2020) and Al-Jamal et al. (2000) description where y is the growth and yield components of onion $(\mathrm{cm}, \mathrm{g})$ and $\mathrm{x}$ is the $\operatorname{SBD}\left(\mathrm{g} . \mathrm{cm}^{-3}\right)$.

Sato et al. (2015) use the concept of soil penetration resistance (PR), found that the relationship between soil water content and soil bulk is non-linear in soybean plants. The model 
parameters explained $>80 \%$ of the variability of PR as a function of SWC and SBD. Regardless of the soil texture, they verify a negative relation between PR and the SWC and the positive association to the SBD. They concluded that, variation of SBD related to SWC in all soil types.
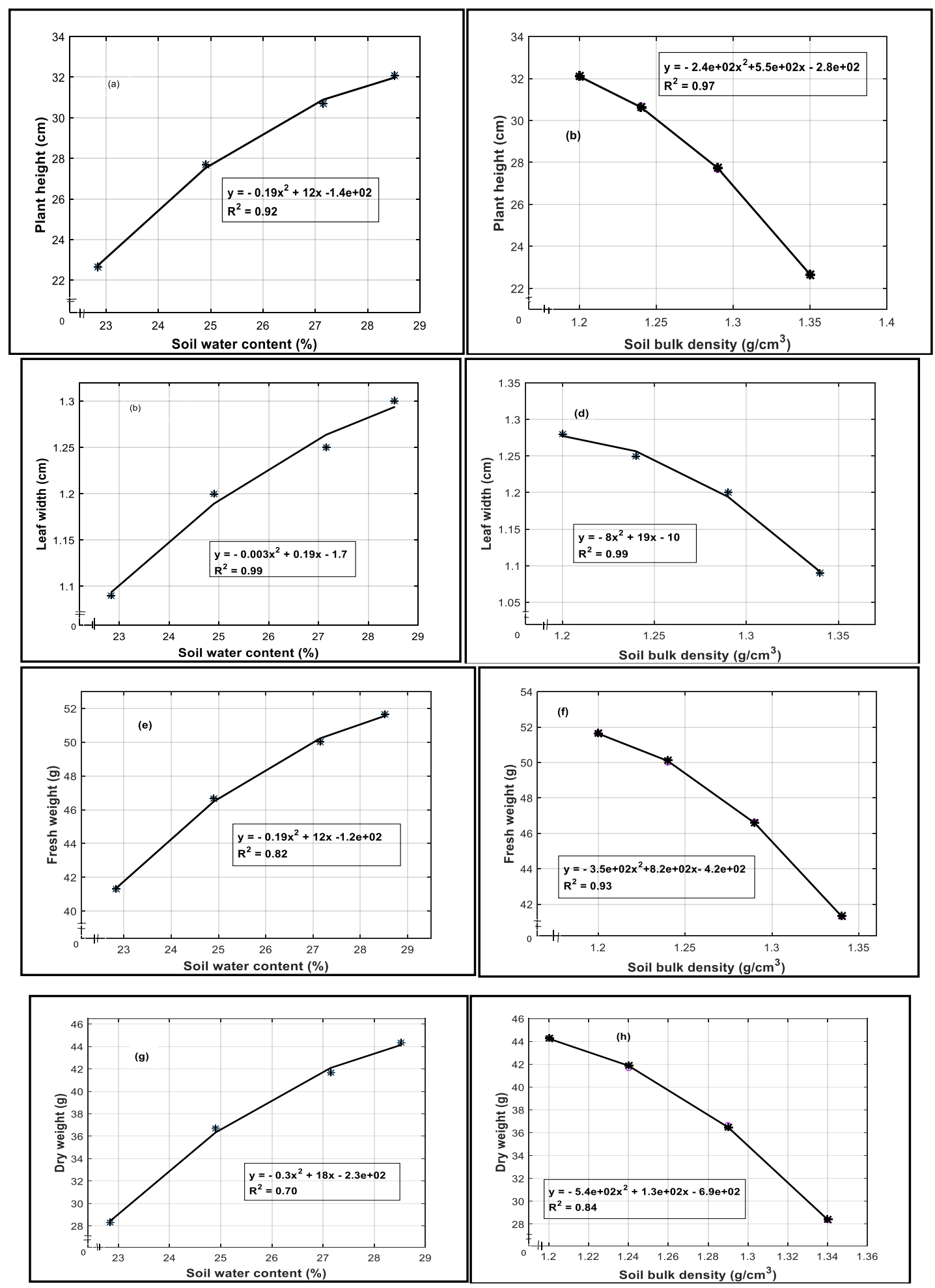

Figure 1. The positive effect of SWC and the negative effect SBD on the growth and yield of onion

\subsection{Correlation Between Soil Water Content and Soil Bulk Density}

Table 3 above showed that the volume of treated water tended to be higher than the soil water content and tended slightly decrease soil bulk. Or in other words, the water treatment has 
directly affected the addition of soil water content in soil and affect the soil bulk density becomes lower with a correlation coefficient of 0.99 (Figure 2). So, the correlation between SWC and SBD has a negative correlation, as stated by Hillel (2004) and (Korenkova and Urik, 2017).Previous researches by Kormanek et al. (2015) and Sato et al. (2015) confirmed that decreasing tendency for root system length with an increase in the level of SBD by the slope of trends line of regression equation in forest tree and soybean plant with correlation coefficient in both cases appear to be significance level.

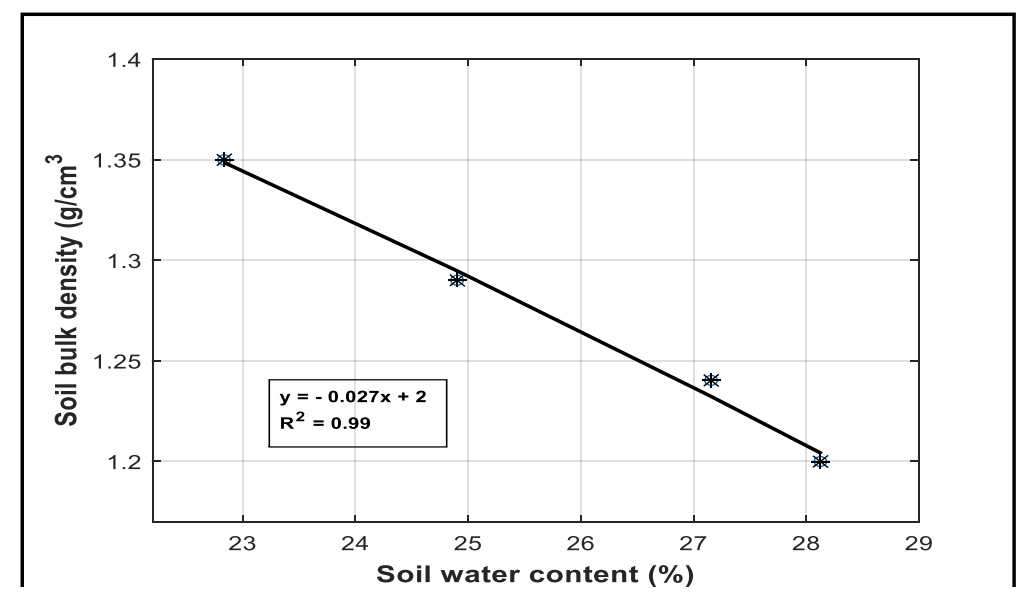

Figure 2. Correlation between SWC and SBD

\section{Conclusion}

This paper emphasizes that water treatment effectively influenced soil water content and soil bulk density reciprocally. The effect of soil water on the growth and yield of onion was an advantage, while the influence of soil bulk was a disadvantage. But if the combinations of both soil water and soil bulk are at the appropriate values, then soil particles and onion seeds are in good contact with another one has been provided increasing yield. The highest onion yield represented by plant height, leaf width, fresh and dry weight occurred at treatment A3V at condition SBD is lowest of $(33.07 \mathrm{~cm}),(1.3 \mathrm{~cm}),(51.67 \mathrm{~g})$, and $(44.33 \mathrm{~g})$, followed other treatment with water treatment is lower but SBD is higher. Eight quadratic equations describing the effect of soil water content and soil bulk density on growth and yield of onion had a high average coefficient of determination $\mathrm{R}^{2}=0.93$. These indicate that the relationship between soil water content and soil bulk density and growth and yield of onion can be explained through the equations. Also, the correlation between SWC and SBD showed that they reciprocal proportional inversely with a coefficient correlation of 0.99 .

\section{Acknowledgments}

Author grateful thank for the local farmers who were helping to provide water for irrigation and pest control. The author also appreciated the laboratory analyst of the Halu Oleo University who has helped with soil analysis. 


\section{References}

Abidin, M. H. Z., Saad, R., Ahmad, F., Wijeyesekera, D., \& Yahya, A.S. (2013). Soil Moisture Content and Density Prediction Using Laboratory Resistivity Experiment. IACSIT International Journal of Engineering and Technology, 5(6), 731-735. https://www.doi.org/10.7763/IJET.V5.652

Ali, M. H. (2017). Irrigation Management for Optimizing Onion Seed Production. Asian Research Journal of Agriculture, 6(2), 1-6. https://www.doi.org/10.9734/ARJA/2017/35863

Al-Jamal, M. S., Sammis, T. W., Ball, S., \& Smeal, D. (2000). Computing the crop water production function for onion. Agricultural Water Management, 46(1), 29-41. https://doi.org/10.1016/S0378-3774(00)00076-7

Bonfante, A., Terribile, F., \& Bouma, J. (2019). Refining physical aspects of soil quality and soil health when exploring the effects of soil degradation and climate change on biomass production: an Italian case study. Soil, 5(1), 1-14. https://doi.org/10.5194/soil-5-1-2019

Brus, D. J., \& Van Den Akker, J. J. (2018). How serious a problem is subsoil compaction in the Netherlands? A survey based on probability sampling. Soil, 4(1), 37-45. https://doi.org/10.5194/soil-4-37-2018

Chakraborty, K., \& Mistri, B. (2017). Estimation of Soil Compaction from Bulk Density and Its Effect on Crop Production: A Case Study of Burdwan - I Block, West Bengal. Indian Journal of Spatial Science, 8(2), 101-107.

Campbell, G. S. (1994). Soil Physics with Basic (Third Impression ed., Vol. 14). Amsterdam, Netherland: Elsevier Science B.V.

Elfadil, A. D., \& Salih H. A. (2017). Effect of soil compaction on shoot and root development and nutrient uptake. European Academic Research, V(7), 3054-3064.

FAO. (2020). Crop production manual. A guide to fruit and vegetable production in the Federated States of Micronesia. (S. Khalid, Ed.) Apia.

Fitsum, G., Woldetsadik, K., \& Alemayhu, Y. (2016). Effect of Irrigation Depth and Nitrogen Levels on Growth and Buld Yield on Onion (Allium cepa L) at algae, Central Rift Valley of Ethiopia. International Journal of Life Science, 5(3), 152-162.

Gautam, E. N., Shringi, E. S., \& Sharma, J. K. D. (2018). Comparison Between the Water Content Determination Method from Oven Dry and Sensor Method. International Journal of Advance Research in Science and Engineering, 07, 59-67.

Ghosh, R. (2013). Effect of Soil Moisture in the Analysis of Undrained Shear Strength of Compacted Clayey Soil. Journal of Civil Engineering and Construction Technology, 4(1), 23-31. https://www.doi.org/10.5897/JCECT12.070

Haghi, D. Z., Shahabi, M., \& Rezaei, H. (2015). Response of Soil Physical Properties and Onion Seed Germination to Irrigation Methods. Journal of Biodiversity and Environmental Sciences (JBES), 6(6), 194-202.

Hanafiah, K. A. (2014). Rancangan Percobaan. Teori dan Aplikasi (15 ed.). Jakarta, Indonesia: Rajawali Pers.

Hanelt, P. (1990). Taxonomi, Evolution and History in Onions and Allied Crops. (b. H. Breuster, $E d$.). Boca Raton, Fla: CRC Press.

Hardjowigeno, S. (1992). Ilmu Tanah (Edisi Revisi ed.). Jakarta, Indonesia: PT Melton Putra

Hillel D. (2004). Introduction to Environmental Soil Physics. San Diego, California, USA: Elsevier Science.

Indoria, A. K., Sharma K. L., Reddy, K. S., \& Rao, C. S. (2016). Role of Soil Physical Properties in Soil Health Management and Crop Productivity in Rainfed Systems-II Management Technology and Crop Productivity. Current Science, 110, 320-328.

Khokhar, K. M. (2017). Environmental and Genotypic Effects on Bulb Development in Onion A Review. Journal of Horticultural Science and Biotechnology, 92(5), 448-454. https://www.doi.org/10.1080/14620316.2017.1314199 
Korenkova, L., \& Urik, M. (2017). Soil Moisture and Its Effect on Bulk Density and Porosity of Intact Aggregates of Three Mollic Soils. Indian Journal of Agricultural Sciences, 82 (2), 172-176.

Kormanek, M., Banach, J., \& Sowa, P. (2015). Effect of Soil Bulk Density on Forest Tree Seedlings. International Agrophysics, 29(1), 67-74. https://www.doi.org/10.1515/intag2015-0003

Manullang, Y., Herawati, R., Handajaningsih, M., Ganefianti, D. W., Haquarsum, E. J. V., \& Sutrawati, M. (2020). Growth and Yield of Lettuce (Lactuca sativa L.) on Peat Soil Supplemented with Cow Manures and Palm Oil Bunches Fertilizer. Akta Agrosia, 23(2), 3946.

Anshar, M., Tohari, Sunarminto, B. H., \& Sulistyaningsih, E. (2011). Pengaruh Lengas Tanah terhadap Pertumbuhan dan Hasil Tiga Varietas Lokal Bawang Merah pada Ketinggian Tempat Berbeda. J. Agroland, 18(1), 8-14.

Nault B., Cranshaw W., \& Alston D. (2011). Farmers Handbook for Onion Production. Kingston, Jamaika: USAID.

Nawas, M. F., Bourrie, G., \& Trolard, F. (2013). Soil Compaction Impact and Modelling. A Review. Agronomy for Sustainable Development, 33, 291-309. https://www.doi.org/10.1007/s13593-011-0071-8

Nikus, O., \& Mulugeta, F. (2010). Onion Seed Production Techniques, A Manual for Extension Agent and Seed Producers. Asella, Ethiopia: FAO/CDMP.

Nunes, J. A. S., Bonfim-Silva, E. M., \& da Silva, T. J. A. (2016). Bulk Density and Water Tensions in the Soil on Corn Root Production. Rev. bras. Engineering Agriculture Ambient, 20, 1-18. https://dx.doi.org/10.1590/1807-1929/agriambi.v20n4p357-363.

Pedersen, H. H., Sorense C. G, Oudshoorn F. W, Krogsgard P. K, Munkholm. (2015). Evaluation of onion production on sandy soils by use of reduced tillage and controled traffic farming with-wide span tractors. Acta Technologica Agriculture, 3, 74-82. https://www.doi.org/10.1515/ata-2015-0015

Phogat, V. K., Tomar, V. S., \& Dahiya, R. (2015). Soil Physics Properties (Chapter 6), In book: Soil Science. An Introduction, Edition First, Publisher: Indian Society of Soil Science.

Sato, M. K., de Lima, H. V., de Oliveira, P. D., \& Rodrigues, S. (2015). Critical Soil Bulk Density for Soybean Growth in Oxisols. International Agrophysics, 29(4), 441-447. https://www.doi.org/10.1515/intag-2015-0050

Shah, A. N., Tanveer, M., Shahzad, B., Yang, G., Fahad, S., Ali, S., Bukhari, M. A., Tung, S. A., Hafeez, A., \& Souliyanonh, B. (2017). Soil Compaction Effects on Soil Health and Crop Productivity: An Overview. Environmental Science and Pollution Research, 24(11), 1005610067. https://www.doi.org/10.1007/s11356-017-8421-y

Tolossa, T. T. (2021). Onion Yield Response to Irrigation Level During Low and High Sensitive Growth Stages and Bulb Quality Under Semi-Arid Climate Conditions of Western Ethiopia. Cogent Food \& Agriculture, 7(1), 1-26. https://doi.org/10.1080/23311932.2020.1859665

Wibisono, D. (2013). Panduan Penyusunan Skripsi, Tesis \& Disertasi. Yogyakarta, Indonesia: CV ANDI OFFSET.

Wichelns, D. (2014). Do estimates of water productivity enhance understanding of farm-level water management?. Water, 6(4), 778-795. https://www.doi.org/10.3390/w6040778

Yahuza, I. (2011). Yield-Density Equation and Their Application for Agronomic Research: A Review. International Journal of Biosciences (IJB), 1(5), 1-17.

Zhang, H., Wang, X., You, M., \& Liu, C. (1999). Water-yield relations and water-use efficiency of winter wheat in the North China Plain. Irrigation Science, 19(1), 37-45.

Zheng, J., Huang, G., Wang, J., Huang, Q., Pereira, L. S., Xu, X., \& Liu, H. (2013). Effects of water deficits on growth, yield and water productivity of drip-irrigated onion (Allium cepa L.) in an arid region of Northwest China. Irrigation Science, 31(5), 995-1008. https://www.doi.org/10.1007/s00271-012-0378-5 